\title{
Heterogeneous Nuclear Ribonucleoprotein A2/B1
}

National Cancer Institute

\section{Source}

National Cancer Institute. Heterogeneous Nuclear Ribonucleoprotein A2/B1. NCI

Thesaurus. Code C97498.

Heterogeneous nuclear ribonucleoproteins A2/B (353 aa, 37 kDa) is encoded by the human HNRNPA2B1 gene. This protein is involved in both RNA splicing and transport. 